\title{
Hyperexcitability, Interneurons, and Loss of GABAergic Synapses in Entorhinal Cortex in a Model of Temporal Lobe Epilepsy
}

\author{
Sanjay S. Kumar ${ }^{1}$ and Paul S. Buckmaster ${ }^{1,2}$ \\ Departments of ${ }^{1}$ Comparative Medicine and ${ }^{2}$ Neurology and Neurological Sciences, Stanford University, Stanford, California 94305
}

\begin{abstract}
Temporal lobe epilepsy is the most common type of epilepsy in adults, and its pathophysiology remains unclear. Layer II stellate cells of the entorhinal cortex, which are hyperexcitable in animal models of temporal lobe epilepsy, provide the predominant synaptic input to the hippocampal dentate gyrus. Previous studies have ascribed the hyperexcitability of layer II stellate cells to GABAergic interneurons becoming "dormant" after disconnection from their excitatory synaptic inputs, which has been reported to occur during preferential loss of layer III pyramidal cells. We used whole-cell recording from slices of entorhinal cortex in pilocarpine-treated epileptic rats to test the dormant interneuron hypothesis. Hyperexcitability appeared as multiple action potentials and prolonged depolarizations evoked in layer II stellate cells of epileptic rats but not controls. However, blockade of glutamatergic synaptic transmission caused similar percentage reductions in the frequency of spontaneous IPSCs in layer II stellate cells of control and epileptic rats, suggesting similar levels of excitatory synaptic input to GABAergic interneurons. Direct recordings and biocytin labeling revealed two major types of interneurons in layer III whose excitatory synaptic drive in epileptic animals was undiminished. Interneurons in layer III did not appear to be dormant; therefore, we tested whether loss of GABAergic synapses might underlie hyperexcitability of layer II stellate cells. Stereological evidence of fewer GABAergic interneurons, fewer gephyrin-immunoreactive punctae, and reduced frequency of spontaneous IPSCs and miniature IPSCs (recorded in tetrodotoxin) confirmed that layer II stellate cell hyperexcitability is attributable, at least in part, to reduced inhibitory synaptic input.
\end{abstract}

Key words: entorhinal cortex; temporal lobe epilepsy; interneurons; electrophysiology; anatomy; stellate cells

\section{Introduction}

Temporal lobe epilepsy is the most common type of epilepsy in adults, often intractable to treatment with anticonvulsants, and its underlying pathophysiology is still poorly understood (Engel et al., 1997). Historically, studies of temporal lobe epilepsy have focused on the hippocampus, and less attention has been given to the entorhinal cortex. Entorhinal layer II stellate cells receive excitatory synaptic input from olfactory structures, parasubiculum, perirhinal cortex, and other neurons in the entorhinal cortex (Witter et al., 1989). In turn, they provide the major excitatory synaptic input to the dentate gyrus (Segal and Landis, 1974; Steward and Scoville, 1976; Ramón y Cajal, 1995). Entorhinal layer III pyramidal neurons receive excitatory synaptic input from olfactory structures, presubiculum, perirhinal cortex, claustrum, amygdala, and other neurons in the entorhinal cortex, and, in turn, they provide excitatory synaptic input to the CA1 field and subiculum (Witter et al., 1989). Neurons in layers II and III re-

Received Aug. 4, 2005; revised March 13, 2006; accepted March 16, 2006.

This work was supported by the National Institutes of Health/National Institute of Neurological Disorders and Stroke. We thank Dr. Xiling Wen, Jennifer Chung, and Alan Anderson for their help with anatomy. This manuscript is dedicated to the memory of Dr. Angel Alonso.

Correspondence should be addressed to Paul Buckmaster, Department of Comparative Medicine, Stanford University, 300 Pasteur Drive, R321 Edwards Building, Stanford, CA 94305-5342. E-mail: psb@stanford.edu.

DOI:10.1523/JNEUROSCI.0064-06.2006

Copyright $\odot 2006$ Society for Neuroscience $\quad$ 0270-6474/06/264613-11\$15.00/0 ceive strong inhibitory synaptic input (de Curtis and Paré, 2004; Woodhall et al., 2005). A variety of interneuron classes have been identified in the entorhinal cortex, but their functional roles, sources of excitatory synaptic input, and laminar specificity of their axonal projections remain unclear.

In animal models of temporal lobe epilepsy, layer II stellate cells are hyperexcitable (Bear et al., 1996; Scharfman et al., 1998; Tolner et al., 2005). Their hyperexcitability does not appear to involve changes in intrinsic electrophysiological properties (Bear et al., 1996; Kobayashi et al., 2003), which are similar to controls (Alonso and Klink, 1993; Jones, 1994). Because of the hyperexcitability of layer II stellate cells, downstream granule cells in the dentate gyrus receive excessive, synchronous, excitatory synaptic input (Buckmaster and Dudek, 1997; Scharfman et al., 1998; Kobayashi et al., 2003), which can be detected as large-amplitude field EPSPs (Bragin et al., 1995) that resemble interictal EEG spikes in patients (Rutecki et al., 1989; Wilson et al., 1990).

The dormant interneuron hypothesis was first proposed as an epileptogenic mechanism in the hippocampus (Sloviter, 1987; Bekenstein and Lothman, 1993). Subsequently, it was advanced as a mechanism for the hyperexcitability of layer II stellate cells in the entorhinal cortex (Du et al., 1995; Bear et al., 1996; Eid et al., 1999; Schwarcz et al., 2000). The results of recent studies are consistent with this hypothesis (van Vliet et al., 2004; Tolner et al., 2005). Specifically, the hypothesis contends that, in the medial 
entorhinal cortex, (1) layer III pyramidal cells provide a major source of excitatory synaptic input to layer III interneurons, and (2) after an epileptogenic injury, GABAergic layer III interneurons survive and maintain inhibitory synapses with their targets, including layer II stellate cells, but they become "dormant" or inactive because their major excitatory afferents (layer III pyramidal cells) are lost. In patients with temporal lobe epilepsy, magnetic resonance imaging reveals shrinkage of the entorhinal cortex (Bernasconi et al., 1999; Jutila et al., 2001; Bartolomei et al., 2005), and histology demonstrates the preferential loss of pyramidal neurons in layer III of the medial entorhinal cortex in patients (Du et al., 1993) (but see Dawodu and Thom, 2005) and animal models (Schwob et al., 1980; Clifford et al., 1987; Du et al., 1995; Ribak et al., 1998) of temporal lobe epilepsy.

Previously, we investigated the short-term consequences of an epileptogenic treatment on GABAergic synaptic input to layer II stellate cells (Kobayashi et al., 2003). That study, however, did not use stereological methods to evaluate GABAergic neuron numbers, anatomically evaluate GABAergic synapses, record directly from GABAergic interneurons, or analyze epileptic animals. The present study addresses these limitations and tests whether hyperexcitability of layer II stellate cells in epileptic rats results from reduced excitatory synaptic drive to layer III interneurons or loss of interneurons and inhibitory synapses.

\section{Materials and Methods}

Animals. All experiments were performed in accordance with National Institutes of Health Guide for the Care and Use of Laboratory Animals and were approved by the Stanford University Institutional Animal Care and Use Committee. A previously described pilocarpine treatment protocol (Turski et al., 1989) was modified (Buckmaster, 2004). Briefly, male Sprague Dawley rats (50-65 d old) were treated with pilocarpine (380 $\mathrm{mg} / \mathrm{kg}$, i.p.) $20 \mathrm{~min}$ after atropine methylbromide (5 mg/kg, i.p.). Approximately $60 \%$ of the treated rats experienced status epilepticus. Diazepam $(10 \mathrm{mg} / \mathrm{kg}$, i.p.) was administered $2 \mathrm{~h}$ after the onset of status epilepticus and repeated as needed. After recovery from status epilepticus, rats were video monitored ( $40 \mathrm{~h} /$ week) for spontaneous seizures. Animals were used for electrophysiological experiments after at least two spontaneous seizures were observed (7-25 d after pilocarpine treatment). Rats were not monitored continuously, and it is possible that they had spontaneous seizures shortly before slice preparation. Control groups included age-matched naive rats and pilocarpine-treated rats that did not experience status epilepticus. There were no significant differences in the anatomical or electrophysiological results from the two types of controls.

Slice preparation and electrophysiology. Rats were deeply anesthetized with pentobarbital ( $75 \mathrm{mg} / \mathrm{kg}$, i.p.) and decapitated, and horizontal slices $(400 \mu \mathrm{m})$ were prepared with a microslicer (VT1000S; Leica, Nussloch, Germany) in a chilled $\left(4^{\circ} \mathrm{C}\right)$ low- $\mathrm{Ca}^{2+}$, low- $\mathrm{Na}{ }^{+}$"cutting solution" containing the following (in $\mathrm{mm}$ ): 230 sucrose, $10 \mathrm{D}$-glucose, $26 \mathrm{NaHCO}_{3}, 2.5$ $\mathrm{KCl}, 1.25 \mathrm{NaH}_{2} \mathrm{PO}_{4}, 10 \mathrm{MgSO}_{4}$, and $0.5 \mathrm{CaCl}_{2}$ (equilibrated with $95 \%$ $\mathrm{O}_{2} / 5 \% \mathrm{CO}_{2}$ ). Slices were allowed to equilibrate in oxygenated artificial CSF (aCSF) (in mu: $126 \mathrm{NaCl}, 26 \mathrm{NaHCO}_{3}, 3 \mathrm{KCl}, 1.25 \mathrm{NaH}_{2} \mathrm{PO}_{4}, 2$ $\mathrm{MgSO}_{4}, 2 \mathrm{CaCl}_{2}$, and $10 \mathrm{D}$-glucose, $\mathrm{pH} 7.4$ ), first at $32^{\circ} \mathrm{C}$ for $1 \mathrm{~h}$ and subsequently at room temperature before being transferred to the recording chamber.

Recordings were obtained at $32 \pm 1^{\circ} \mathrm{C}$ from neurons in the medial entorhinal cortex under Nomarski optics (Nikon, Tokyo, Japan) using a visualized infrared setup (Hamamatsu, Shizouka, Japan). Cell morphology and location within the various cortical lamina could be identified. Recording electrodes (1.2-2.0 $\mu \mathrm{m}$ tip diameters, 3-6 M ) contained (in mM) 100 potassium gluconate, $40 \mathrm{HEPES}, 10 \mathrm{EGTA}, 5 \mathrm{MgCl}_{2}$, 2 disodium-ATP, 0.3 sodium-GTP, and 20 biocytin for current-clamp recordings and 120 cesium methanesulfonate, 10 HEPES, $8 \mathrm{NaCl}, 2$ magnesium-ATP, 0.3 sodium-GTP, 5 QX-314 [lidocaine $N$-ethylbromide and $N$-(2,6-dimethylphenylcarbamoylmethyl)triethylammonium bromide], 0.1 BAPTA, and 20 biocytin for voltage-clamp recordings. Internal solutions were adjusted to a $\mathrm{pH}$ of 7.3 with $\mathrm{KOH}$ or $\mathrm{CsOH}$ and an osmolarity of $300 \mathrm{mOsm}$. The presence of QX-314 and cesium in the pipette solution precluded the recording of $\mathrm{GABA}_{\mathrm{B}}$ receptor-mediated IPSCs. Slices were maintained in oxygenated $\left(95 \% \mathrm{O}_{2}\right.$ and $\left.5 \% \mathrm{CO}_{2}\right) \mathrm{aCSF}$, and drugs and chemicals were applied via the perfusate $(2 \mathrm{ml} / \mathrm{min})$. The following compounds were bath applied as required for specific protocols: $\mathrm{D}(-)$-2-amino-5-phosphonopentanoic acid (D-APV), 2,3-dihydro-6-nitro-7-sulfamoyl-benzo( $f$ )quinoxaline (NBQX) (diluted in dimethylsulfoxide, $<0.1 \%$ final concentration), tetrodotoxin (TTX), and picrotoxin (all from Sigma, St. Louis, MO).

Concentric bipolar electrodes (CB-XRC75; Frederick Haer Company, Brunswick, ME) with $75 \mu \mathrm{m}$ tip diameters were positioned in layer I in close proximity to recorded neurons in layer II, and depolarizing constant current pulses, $100-150 \mu \mathrm{s}$ in duration and 50-500 $\mu \mathrm{A}$ in amplitude, were applied at low frequencies $(0.1-0.3 \mathrm{~Hz})$ to evoke action potentials. Postsynaptic currents and potentials were recorded with an Axopatch-1D amplifier and pClamp software (Molecular Devices, Palo Alto, CA), filtered at $1-2 \mathrm{kHz}$ (10 kHz for current clamp), digitized at $10-20 \mathrm{kHz}$, and stored digitally. Series resistance was monitored continuously, and those cells in which this parameter exceeded $15 \mathrm{M} \Omega$ or changed by $>20 \%$ were rejected. Series resistance compensation was not used. During experiments, putative interneurons in layer III were distinguished from principal cells by single action potential waveforms, firing frequency, degree of spike frequency accommodation, and dynamic range, and they were subsequently identified by biocytin labeling. Spike afterhyperpolarization amplitude was measured from the prespike baseline to the maximum amplitude of the afterhyperpolarization. Spontaneous (s) and miniature ( $\mathrm{m}$ ) IPSC and EPSC data, obtained from 2-minlong continuous recordings, were analyzed using Mini Analysis (Synaptosoft, Decatur, GA). The threshold (T) for event detection was set at three times the root mean square noise level. Average root mean square noise levels were similar in control and epileptic groups $(p \geq 0.4)$. Software-detected events were visually verified, and their frequency and amplitude were measured. These parameters could be measured accurately by the software despite the presence of overlapping events. Miniature postsynaptic currents were isolated using TTX $(1 \mu \mathrm{M})$.

Neuronal-specific nuclear protein-biocytin immunohistochemistry. To visualize biocytin-labeled neurons after recording, slices were fixed in $4 \%$ paraformaldehyde in $0.1 \mathrm{~m}$ phosphate buffer $(\mathrm{PB})$ at $4^{\circ} \mathrm{C}$ for at least $24 \mathrm{~h}$. After fixation, slices were stored in 30\% ethylene glycol and 25\% glycerol in $50 \mathrm{~mm} \mathrm{~PB}$ at $-20^{\circ} \mathrm{C}$, before being processed using a whole-mount protocol with counterstaining by neuronal-specific nuclear protein $(\mathrm{NeuN})$ immunocytochemistry. Slices were rinsed in $0.5 \%$ Triton X-100 and $0.1 \mathrm{~m}$ glycine in $0.1 \mathrm{M} \mathrm{PB}$ and then placed in a blocking solution containing $0.5 \%$ Triton X-100, 2\% goat serum (Vector Laboratories, Burlingame, CA), and 2\% bovine serum albumin in $0.1 \mathrm{M} \mathrm{PB}$ for $4 \mathrm{~h}$. Slices were incubated in mouse anti-NeuN serum (1:1000, MAB377; Chemicon, Temecula, CA) in blocking solution overnight. After a rinsing step, slices were incubated with the fluorophores Alexa Fluor 594 streptavidin $(5 \mu \mathrm{g} / \mathrm{ml})$ and Alexa Fluor 488 goat anti-mouse $(10 \mu \mathrm{g} / \mathrm{ml}$; Invitrogen, Carlsbad, CA) in blocking solution overnight. Slices were rinsed, mounted on slides, and coverslipped with Vectashield (Vector Laboratories) before being examined with a confocal microscope (LSM 5 Pascal; Zeiss, Oberkochen, Germany).

Gephyrin immunocytochemistry. To visualize and quantify putative GABAergic synapses, we used immunohistochemistry, confocal laser scanning microscopy, and stereology. As in all the anatomical experiments in this study, investigators processing the tissue and analyzing the data were blind to the experimental group. Rats were killed by urethane overdose ( $2 \mathrm{~g} / \mathrm{kg}$, i.p.), perfused $(30 \mathrm{ml} / \mathrm{min}$ ) with $2 \%$ paraformaldehyde in $0.1 \mathrm{M} \mathrm{PB}$ for $10 \mathrm{~min}$, and then postfixed in the same solution for $1 \mathrm{~h}$. After cryoprotection in $30 \%$ sucrose in $0.1 \mathrm{M} \mathrm{PB}$, horizontal brain sections (30 $\mu \mathrm{m}$ thick) were prepared and mounted onto gelatin-coated glass slides, rinsed with $0.1 \mathrm{M}$ Tris-buffered saline (TBS), and placed for $2 \mathrm{~h}$ in a blocking solution containing $0.05 \mathrm{M}$ TBS, $0.3 \%$ Triton X-100, 2\% bovine serum albumin, and $3 \%$ goat serum. After a rinsing step, sections were incubated in mouse anti-gephyrin serum (1:1000, clone mAb7a; Synaptic Systems, Goettingen, Germany), 0.05 м TBS, 0.3\% Triton $\mathrm{X}-100,0.2 \%$ bovine serum albumin, and $1 \%$ goat serum overnight at 


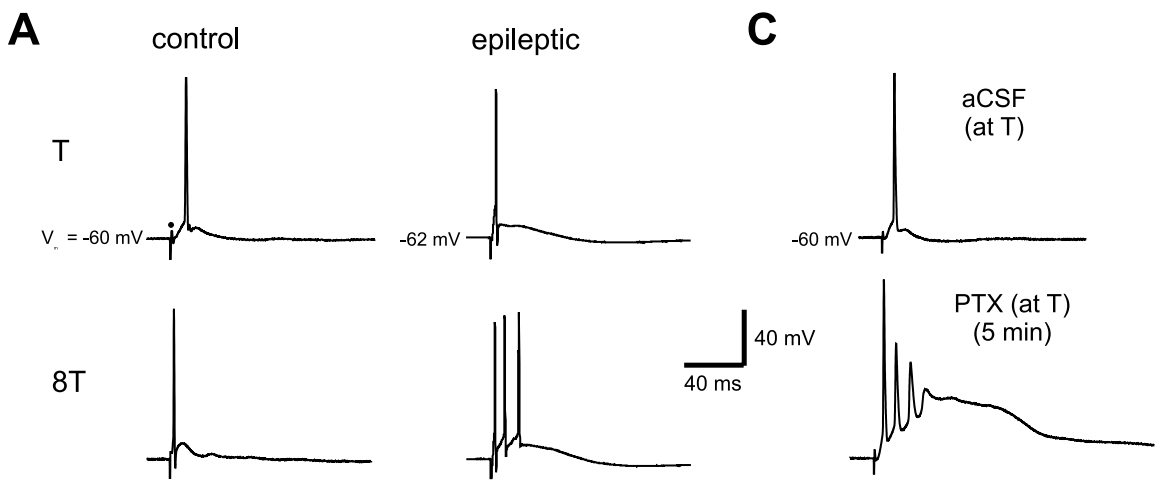

B
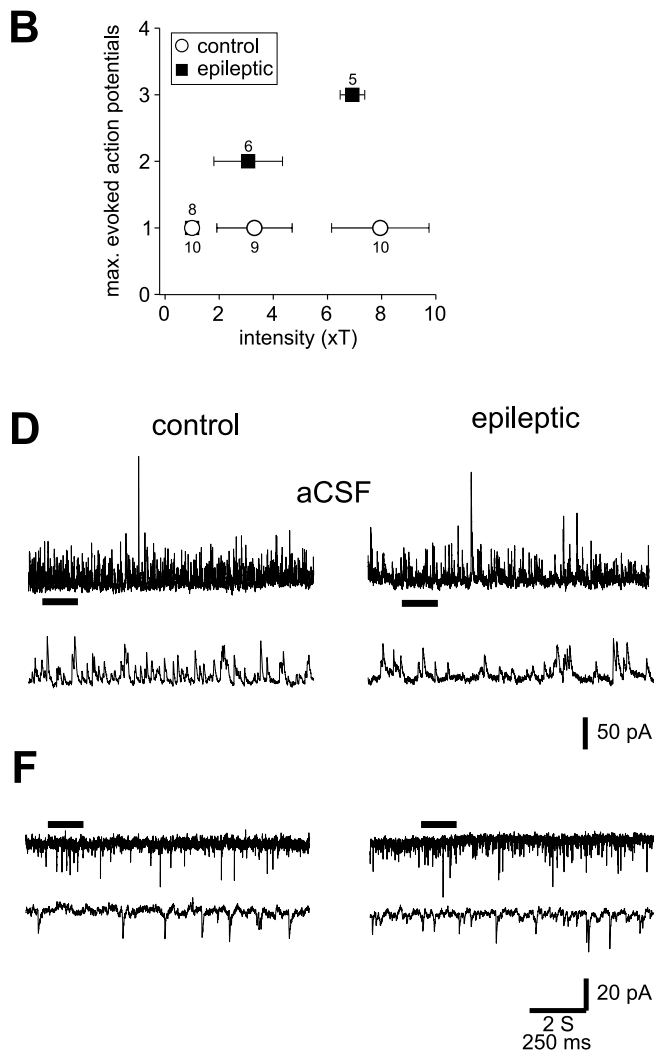

E

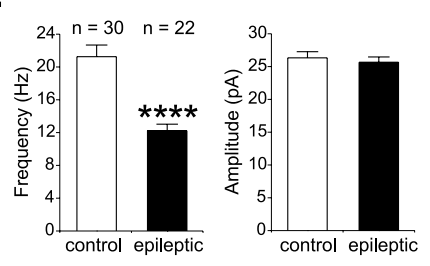

G

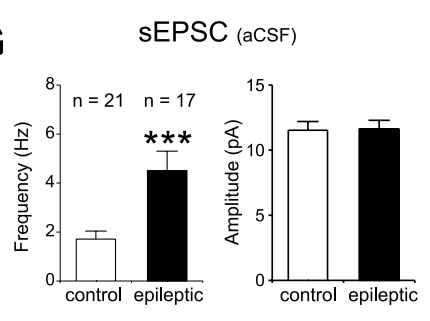

I-II because it contains the somata and $91 \%$ of the total dendritic length of layer II cells (Buckmaster et al., 2004). Nissl-stained sections (1in-6 series) were used to outline layers I-II within the borders of the medial entorhinal cortex. Borders were identified according to Mulders et al. (1997) and Paxinos and Watson (1998). The deep border of layer II was indicated by the end of the large, Nissl-stained layer of neurons. The medial border of the entorhinal cortex was indicated by the parasubiculum. The border between the medial and lateral entorhinal cortex was indicated by characteristics of layers V-VI: the loss of columnar arrangement of neurons and transition from a shallow to deeper layer with larger neurons and lower neuron density (Mulders et al., 1997). Stereo Investigator software (MicroBrightField, Colchester, VT) was used to specify sample sites (counting grid, $900 \times 900 \mu \mathrm{m}$; counting block, $9.2 \times 9.2 \times 2.0 \mu \mathrm{m})$ on Nissl-stained sections. An average of 10 sites distributed in 13 sections was sampled per rat. Sample sites were identified on corresponding, adjacent gephyrinstained sections and analyzed with a confocal laser scanning microscope equipped with a $100 \times$ objective and $10 \times$ zoom setting. Sample sites consisted of seven images per stack (0.4 $\mu \mathrm{m}$ separation) (supplemental Fig. 1, available at www.jneurosci.org as supplemental material). Within a counting block, gephyrinpositive punctae were tallied unless they were visible in the most superficial section of the stack or overlapped the left or bottom borders of the counting frame. An average of 143 punctae per rat was counted.

Glutamic acid decarboxylase in situ hybridization. Adult rats were killed by an anesthetic overdose $(2 \mathrm{~g} / \mathrm{kg}$ urethane, i.p.) and perfused intra-aortically at $30 \mathrm{ml} / \mathrm{min}$ for $2 \mathrm{~min}$ with $0.9 \% \mathrm{NaCl}$, followed by $4 \%$ paraformaldehyde in $0.1 \mathrm{M} \mathrm{PB}, \mathrm{pH} 7.4$, at $4^{\circ} \mathrm{C}$ for $30 \mathrm{~min}$. Brains were postfixed overnight in the same fixative at $4^{\circ} \mathrm{C}$ and then cryoprotected. One hemisphere was sectioned horizontally $(30 \mu \mathrm{m})$. Sections were collected in 30\% ethylene glycol and $25 \%$ glycerol in $50 \mathrm{~mm} \mathrm{~PB}$ and stored at $-20^{\circ} \mathrm{C}$ until additional processing. A 1-in- 6 series of sections was processed for Nissl staining with $0.25 \%$ thionin.

To visualize GABAergic neurons, we used in situ hybridization for the mRNA encoding glutamic acid decarboxylase-65 (GAD65) according to previously described protocols (Buckmaster and Jongen-Rêlo, 1999). The GAD65 cDNA (kindly provided by Drs. A. Tobin and N. Tillakaratne, University of California at Los Angeles, Los Angeles, CA) was $\sim 2.4 \mathrm{~kb}$ and was isolated from a $\lambda$ ZapII library from adult rat hippocampus (Erlander et al., 1991). RNA probes were produced by transcription of

$4^{\circ} \mathrm{C}$. Sections were subsequently rinsed, incubated with Alexa Fluor 488 goat anti-mouse ( $10 \mu \mathrm{g} / \mathrm{ml}$; Invitrogen ), $0.05 \mathrm{~m}$ TBS, $0.3 \%$ Triton X-100, and $2 \%$ bovine serum albumin for $3 \mathrm{~h}$ at room temperature and coverslipped with Vectashield mounting media (Vector Laboratories). An adjacent series of sections was processed for Nissl staining with $0.25 \%$ thionin.

The optical fractionator method (West et al., 1991) was used to estimate the total number of gephyrin-immunoreactive punctae in layers I-II of the medial entorhinal cortex. We confined the analysis to layers
GAD65 DNA using a nonradioactive RNA labeling kit (Roche, Indianapolis, IN). Starting from a random position in the dorsal brain, sections were sampled (1-in-6 series), washed in $10 \mathrm{~mm}$ PBS, and incubated sequentially in $0.01 \%$ Triton X-100 in PBS, $0.2 \mu \mathrm{g} / \mathrm{ml}$ proteinase $\mathrm{K}$ (Roche) in $50 \mathrm{~mm}$ Tris, pH 7.4, $5 \mathrm{~mm}$ EDTA (Sigma), and $2 \mathrm{mg} / \mathrm{ml}$ glycine (Roche) in PBS. Sections prehybridized for $1 \mathrm{~h}$ in a solution containing $50 \%$ formamide (Sigma), $750 \mathrm{~mm} \mathrm{NaCl}, 25 \mathrm{~mm}$ EDTA, $25 \mathrm{~mm}$ piperazine$N, N^{\prime}$-bis 2-ethanesulfonic acid (Roche), $0.2 \%$ sodium dodecyl sulfate, 
$250 \mu \mathrm{g} / \mathrm{ml}$ poly(A) (Roche), and $250 \mu \mathrm{g} / \mathrm{ml}$ salmon sperm DNA (Roche). Sections were hybridized for $16-19 \mathrm{~h}$ in a humid chamber at $50^{\circ} \mathrm{C}$ in a solution consisting of the prehybridization solution with the addition of the digoxigenin-labeled RNA probe at a concentration of $2-4 \mu \mathrm{l} / \mathrm{ml}$, with $100 \mathrm{~mm}$ dithiothreitol (Sigma), 4\% dextran sulfate (Sigma), and 250 $\mu \mathrm{g} / \mathrm{ml}$ tRNA (Roche). After hybridization, sections were subjected to RNase treatment and stringency washes as described previously. Sections were processed for immunodetection of the digoxigenin label with reagents of a nonradioactive nucleic acid detection kit (Roche), mounted on gelatin-coated slides, and coverslipped with Crystalmount (Biomedia, Foster City, CA) and Permount.

The optical fractionator method (West et al., 1991) was used to estimate the total number of GAD-positive neurons in the medial entorhinal cortex of one cerebral hemisphere. Neurons were counted with a microscope (Nikon) equipped with a motorized stage (Ludl Electronic Products, Hawthorne, NY) and Lucivid and Stereo Investigator software (MicroBrightField). Cells were viewed with a $100 \times$ objective and were considered to be GAD-positive if they were stained more intensely than background levels. The counting frame was $100 \times 100 \mu \mathrm{m}$, and the counting grid was $600 \times 600 \mu \mathrm{m}$, so an average of $16 \%$ of the total area was randomly and systematically sampled. An average of 13 sections per rat was analyzed. Total section thickness was used as the disector height. Only GAD-positive somata not cut at the upper surface of the section were counted. This modification of the optical fractionator method facilitates the analysis of tissue sectioned thinly to enhance staining; however, it increases the probability of underestimating total neuron numbers. It is unlikely to affect the relative values of control and epileptic rats, because both groups were analyzed identically. An average of 160 neurons per rat was counted. Neuron density was calculated by dividing the total number of GAD-positive neurons by the total volume of the medial entorhinal cortex, which was estimated by the Cavalieri principle. To estimate the number of GAD-positive neurons in layers I-II, III, and $\mathrm{V}-\mathrm{VI}$, the total number of GAD-positive neurons in all layers was multiplied by the percentage of neurons counted in the respective layers for each animal.

To estimate the number of Nissl-stained neurons in layers I-II, III, and V-VI of the medial entorhinal cortex, the optical fractionator method was used as described above. The middle of lamina dissecans demarcated the border between layer III and V-VI. A 1-in-6 series of sections was analyzed. The counting frame was $50 \times 50 \mu \mathrm{m}$, and the counting grid was $500 \times 500 \mu \mathrm{m}$ for layers I-II and $600 \times 600 \mu \mathrm{m}$ for layers III and V-VI. Nissl-stained neuronal nuclei that were not cut at the upper surface of the section were counted. An average of 149, 138, and 200 neurons per rat was counted for layers I-II, III, and V-VI, respectively. The total number of neurons in all layers of the medial entorhinal cortex was obtained by summing the number in layers I-II, III, and V-VI for each animal.

All statistical values are presented as mean \pm SEM. Statistical differences were measured using the unpaired Student's $t$ test, unless indicated otherwise.

\section{Results}

\section{Layer II stellate cells are hyperexcitable in epileptic rats}

Whole-cell current-clamp recordings were obtained from stellate cells in layer II of the medial entorhinal cortex (resting potential, $-58 \pm 0.3 \mathrm{mV} ; n=38$ cells). Action potential threshold (T) was determined by stimulating fibers in layer $\mathrm{I}$, and stimulus intensity was measured as multiples of T. Threshold was determined by increasing stimulus intensity until a single action potential could be evoked on $\sim 50 \%$ of the trials. Layer II stellate cells from epileptic rats fired multiple action potentials in response to single shocks of increasing stimulus intensity (Fig. 1A,B). Analyzing responses evoked at $\mathrm{T}$ that did not trigger an action potential revealed that EPSPs in epileptic rats had larger average halfwidths and areas compared with controls $(43 \pm 6$ vs $6 \pm 2 \mathrm{~ms}, p<$ $0.0001 ; 484 \pm 74$ vs $97 \pm 35 \mathrm{mV} / \mathrm{ms}, p<0.0001 ; n=8$ and 10 cells, respectively). Application of the $\mathrm{GABA}_{\mathrm{A}}$ receptor antagonist picrotoxin $(50 \mu \mathrm{M})$ to control tissue produced larger depo-
Table 1. Frequency and amplitude of PSCs in layer II stellate cells and interneurons in layer III of the medial entorhinal cortex in control and epileptic rats

\begin{tabular}{ccc}
\hline & Control & Epileptic \\
\hline $\begin{array}{c}\text { Layer II stellate cells } \\
\text { SIPSCs }\end{array}$ & $(n=30)$ & $(n=22)$ \\
Frequency (Hz) & $21.3 \pm 1.4$ & $12.2 \pm 0.8^{* * * *}$ \\
Amplitude (pA) & $26.3 \pm 0.9$ & $25.7 \pm 0.8$ \\
mIPSCs & $(n=23)$ & $(n=20)$ \\
Frequency & $14.4 \pm 1.4$ & $8.6 \pm 0.8^{* *}$ \\
Amplitude & $21.2 \pm 1.0$ & $22.1 \pm 0.8$ \\
sEPSCs & $(n=21)$ & $(n=17)$ \\
Frequency & $1.7 \pm 0.3$ & $4.5 \pm 0.8^{* * *}$ \\
Amplitude & $11.5 \pm 0.7$ & $11.6 \pm 0.7$ \\
mEPSCs & $(n=10)$ & $(n=8)$ \\
Frequency & $1.5 \pm 0.4$ & $0.8 \pm 0.2$ \\
Amplitude & $9.8 \pm 0.6$ & $9.8 \pm 0.7$ \\
Layer III interneurons & & \\
Type IsEPSCs & $(n=13)$ & $(n=7)$ \\
Frequency & $13.7 \pm 2.0$ & $18.1 \pm 2.2$ \\
Amplitude & $25.2 \pm 1.9$ & $28.8 \pm 2.5$ \\
Type II sEPSCs & $(n=11)$ & $(n=7)$ \\
Frequency & $2.9 \pm 1.2$ & $3.2 \pm 1.4$ \\
Amplitude & $13.7 \pm 1.0$ & $14.9 \pm 1.6$ \\
\hline
\end{tabular}

Values are mean \pm SEM. The total number of cells tested $(n)$ is indicated. Statistically significant differences between epileptic and control groups are indicated: ${ }^{* *} p<0.005$, ${ }^{* * *} p<0.001$, ${ }^{* * *} p<0.0001, t$ test.

larizing potentials and multiple action potentials, similar to the responses of epileptic animals in normal aCSF (Fig. 1C). Prolonged depolarizations with multiple action potentials also were observed in layer II stellate cells in other models of temporal lobe epilepsy in which layer III neuron loss was produced by intense and prolonged electrical stimulation of the ventral hippocampus (Bear et al., 1996) or by injection of aminooxyacetic acid into the entorhinal cortex (Scharfman et al., 1998). Together, these data confirm that layer II stellate cells in epileptic rats are hyperexcitable and suggest that the mechanism may involve reduced inhibition.

We next obtained whole-cell voltage-clamp recordings of spontaneous PSCs to evaluate the inhibitory and excitatory synaptic drive to layer II stellate cells. In normal aCSF, the average frequency of sIPSCs (outward events at the holding potential of 0 $\mathrm{mV}$ ) in layer II stellate cells from epileptic rats was $57 \%$ of controls, but average amplitude was similar (Table 1, Fig. 1D,E). These data suggest that reduced inhibition contributes to the hyperexcitability of layer II cells. Conversely, the average frequency of sEPSCs (inward events at the holding potential of -60 $\mathrm{mV}$ ) in epileptic rats was elevated to $265 \%$ of control, and average amplitude was similar (Table 1, Fig. $1 F, G$ ). More frequent sEPSCs may result from reduced inhibition and subsequent increased spontaneous activity of local excitatory circuits, more excitatory synapses with layer II stellate cells, or increased probability of action potential-dependent neurotransmitter release. To distinguish between these possibilities, we recorded mEPSCs in layer II stellate cells and found that, whereas mEPSC amplitude was normal under epileptic conditions, mEPSC frequency tended to be smaller in the epileptic animals compared with controls (Table 1). This trend is inconsistent with increases in the number of excitatory synapses and/or probability neurotransmitter release and suggests instead that layer II stellate cells lose some excitatory synaptic input when the vulnerable population of layer III 

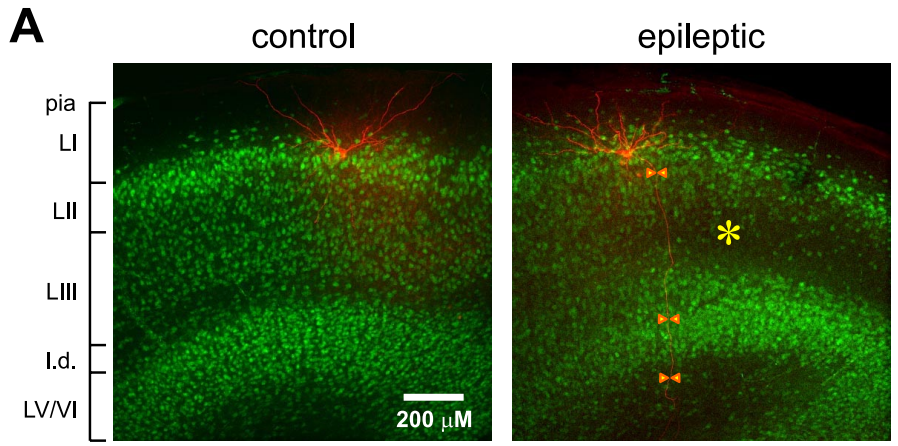

B

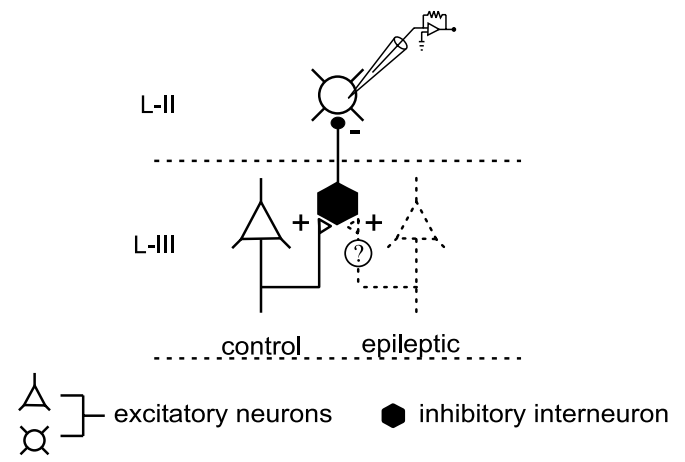

C

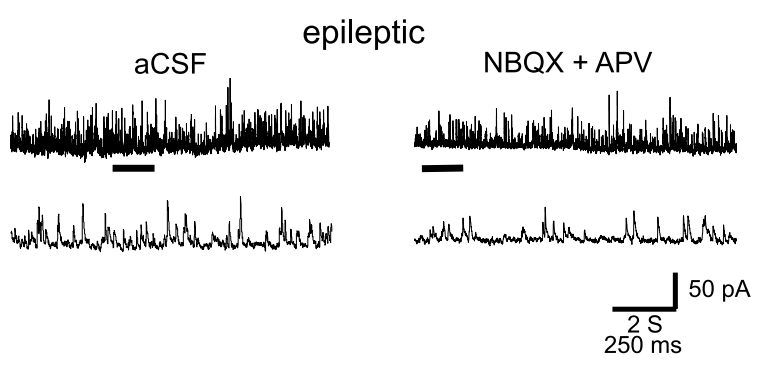

D
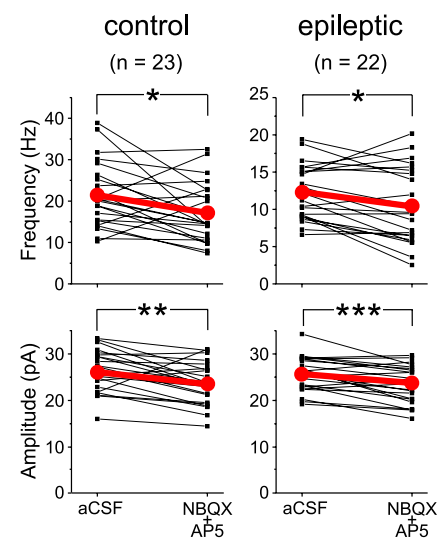

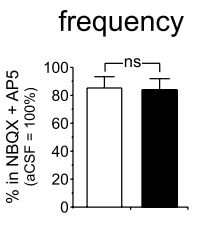

amplitude

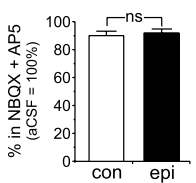

Figure 2. A pharmacological test indicates that interneurons are not disconnected from excitatory synaptic input in the medial entorhinal cortex of epileptic rats. $\boldsymbol{A}$, The medial entorhinal cortex in control and pilocarpine-treated epileptic rats. Recorded neurons were identified morphologically by biocytin labeling (red). Counterstaining for NeuN immunoreactivity (green) revealed the layers of the medial entorhinal cortex (LI-LVI; I.d., lamina dissecans) and the loss of layer III neurons in the epileptic rat (*). A rrowheads in the epileptic slice point to the primary axon of the recorded layer II stellate cell. B. The schematic diagram illustrates the dormant interneuron hypothesis of layer II stellate cell hyperexcitability. In epileptic animals, inhibitory interneurons in layer III are hypothesized to become less active after being "disconnected" from a normal source of excitatory synaptic input: layer III pyramidal cells. This model predicts that the frequency of sIPSCs (but not mIPSCs) in layer II stellate cells will be reduced and be less sensitive to glutamate receptor blockade in epileptic rats. C, Records of sIPSCs from a layer Il stellate cell of an epileptic animal in normal aCSF and after bath application of glutamatergic receptor blockers (10 $\mu \mathrm{m} \mathrm{NBQX}$ and $50 \mu \mathrm{M} \mathrm{D}-\mathrm{APV}$ ). Note the reduction in sIPSC frequency. D, A comparison between control (con) and epileptic (epi) groups of the changes in sIPSC frequency and amplitude affected by glutamatergic blockers. Thin black lines are data from individual cells. Thick red lines are group averages. Similar percentage reductions occur in the control and epileptic groups. Error bars indicate SEM. ${ }^{*} p<0.05,{ }^{* *} p<0.005$, ${ }^{* * *} p<0.001$, paired $t$ test. ns, Not statistically significant; $p>0.7, t$ test.

excitatory neurons dies after pilocarpine-induced status epilepticus. It is unlikely that this trend toward less frequent mEPSCs in epileptic rats is attributable to relatively small-amplitude events being buried in noise because mEPSC amplitudes were normally distributed and averages were identical in both groups.

\section{A pharmacological assay for excitatory synaptic input to GABAergic interneurons}

The dormant interneuron hypothesis contends that GABAergic interneurons lose excitatory synaptic input when glutamatergic layer III pyramidal cells preferentially die during epileptogenic injuries (Fig. $2 A, B$ ). If so, then because of the loss of glutamatergic synapses with interneurons, glutamate receptor blockade should have a smaller effect on interneuron activity and, consequently, sIPSC frequency in layer II stellate cells should be less affected in epileptic rats compared with controls. We tested this prediction by comparing sIPSCs in layer II stellate cells of control and epileptic rats, first in normal aCSF and then in $10 \mu \mathrm{M}$ NBQX and $50 \mu \mathrm{M}$ D-APV (Fig. 2C). Glutamate receptor blockade reduced sIPSC frequency in controls $(21.3 \pm 1.4$ vs $17.2 \pm 1.5 \mathrm{~Hz}$; $p<0.05$, paired $t$ test $)$ and in epileptic rats (12.2 \pm 0.8 vs $10.5 \pm$ $1.1 \mathrm{~Hz} ; p<0.05$ ) (Fig. 2D). The average percentage reduction (aCSF, 100\%) was similar in both groups [85 \pm 8 (control) vs $84 \pm 6 \%$ (epileptic); $p>0.8$ ] (Fig. $2 D$ ), suggesting that a normal level of excitatory synaptic drive to inhibitory interneurons persists in epileptic animals.

Table 2. Intrinsic electrophysiological properties of interneurons and pyramidal cells in layer III of the medial entorhinal cortex in control and epileptic rats

\begin{tabular}{|c|c|c|c|c|}
\hline & Type I interneuron & Type Il interneuron & Layer III pyramidal cell & Significant differences \\
\hline Resting membrane potential (mV) & $\begin{array}{r}-64 \pm 1.3 \\
(n=28)\end{array}$ & $\begin{array}{c}-54 \pm 1.1 \\
(n=25)\end{array}$ & $\begin{array}{c}-55 \pm 1.5 \\
(n=9)\end{array}$ & $\|=$ Pyr $>1$ \\
\hline Membrane resistance (M $\Omega$ ) & $\begin{array}{c}143 \pm 11 \\
(n=28)\end{array}$ & $\begin{array}{c}382 \pm 47 \\
(n=25)\end{array}$ & $\begin{array}{l}49 \pm 3 \\
(n=5)\end{array}$ & $\|>I=P y r$ \\
\hline Membrane capacitance (pF) & $\begin{array}{l}51 \pm 3 \\
(n=28)\end{array}$ & $\begin{array}{l}51 \pm 1 \\
(n=25)\end{array}$ & $\begin{array}{c}130 \pm 9 \\
(n=5)\end{array}$ & Pyr $>I=\|$ \\
\hline Action potential half-width (ms) & $\begin{array}{c}0.2 \pm 0.01 \\
(n=11)\end{array}$ & $\begin{array}{c}0.4 \pm 0.01 \\
(n=11)\end{array}$ & $\begin{array}{c}0.5 \pm 0.04 \\
(n=9)\end{array}$ & Pyr $=\|>1$ \\
\hline Spike afterhyperpolarization amplitude (mV) & $\begin{array}{c}31 \pm 1.3 \\
(n=11)\end{array}$ & $\begin{array}{c}38 \pm 1.5 \\
(n=11)\end{array}$ & $\begin{array}{c}7 \pm 0.4 \\
(n=9)\end{array}$ & $\|>I>$ Pyr \\
\hline
\end{tabular}




\section{Excitatory synaptic drive to layer III interneurons}

Recording from inhibitory interneurons could provide a more direct evaluation of their excitatory synaptic drive. However, neither the electrophysiological types of GABAergic interneurons present in the medial entorhinal cortex nor their excitatory synaptic drive have been adequately characterized. To address these issues, we obtained whole-cell recordings from layer III interneurons in control and epileptic rats. Interneurons were distinguished from layer III pyramidal cells based on action potential discharge profile, attributes of individual action potentials, and passive membrane properties (Table 2). Compared with pyramidal cells, individual action potentials in interneurons were briefer and followed by larger spike afterhyperpolarizations (Fig. 3). In response to equivalent current injections, interneurons discharged action potentials faster than pyramidal cells. Anatomically, layer III pyramidal cells were identified by their apical dendrite, a primary axon that projected toward the angular bundle, and dendrites densely covered with spines (data not shown).

Thirty-eight interneurons were recorded that could be classified into two distinct groups, which were designated as type I and type II. Type I interneurons had a dense axonal plexus in the local vicinity of the cell body that extended superficially into layer II, aspiny dendrites, and a multipolar dendritic arbor that included extensions into layer I (Fig. $4 A$ ). In contrast, type II interneurons had axons that extended locally with some collaterals projecting to and ramifying in layer I. The dendrites of type II interneurons were sparsely spiny, and the multipolar dendritic arbor tended to extend into deeper layers. Type I interneurons fired rapidly, with frequencies reaching up to $300 \mathrm{~Hz}$, and tended to have a more hyperpolarized resting membrane potential than type II interneurons, which had lower firing frequencies, reaching only up to $90 \mathrm{~Hz}$, and displayed prominent sag currents and rebound burst firing (Table 2, Fig. 4B). In control animals, the frequency and amplitude of sEPSCs were larger in type I than in type II interneurons (Table 1, Fig. 4C,D), suggesting that type I interneurons had the greatest potential for impact by synaptic disconnection.

The finding that pharmacological blockade of excitatory synapses caused similar percentage reductions in the frequency of sIPSCs of layer II stellate cells in control and epileptic animals (Fig. 2D) suggested that GABAergic interneurons in epileptic rats receive a normal level of excitatory synaptic input. Consistent with this finding, sEPSC frequency and amplitude in type I interneurons were not reduced in epileptic rats (frequency, 132\%; amplitude, $114 \%$ of controls; $p>0.15$ for both) (Table 1, Fig. $4 E, F)$. Similar results were obtained for type II interneurons (frequency, 109\%; amplitude, 109\% of controls; $p>0.5$ for both).

\section{Loss of inhibitory synaptic input to layer II stellate cells in epileptic animals}

We evaluated mIPSCs of layer II stellate cells to test whether their hyperexcitability might be attributable to the loss of inhibitory synapses. Miniature IPSC frequency in epileptic rats was 59\% of controls, whereas amplitude was similar in both groups (Table 1, Fig. 5). These findings suggest that layer II stellate cells in epileptic rats receive fewer inhibitory synapses or their GABAergic synapses have reduced probability of neurotransmitter release.

Anatomical methods were used to evaluate GABAergic synapses. Gephyrin, a marker for GABAergic synapses (Essrich et al., 1998; Giustetto et al., 1998), was used to quantify putative inhibitory synapses in layers I-II in which stellate cell somata and dendrites are located (Fig. 6). Stereological estimates yielded an average of $165 \pm 18$ million gephyrin-immunoreactive punctae per medial entorhinal cortex (layers I-II only) in control animals
A

\section{Pyramidal cell}

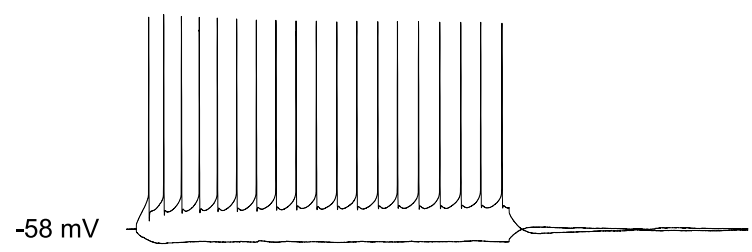

Type I interneuron

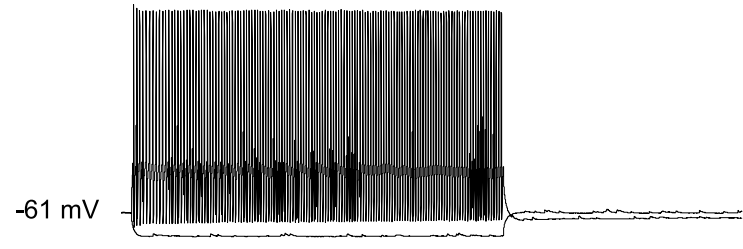

Type II interneuron

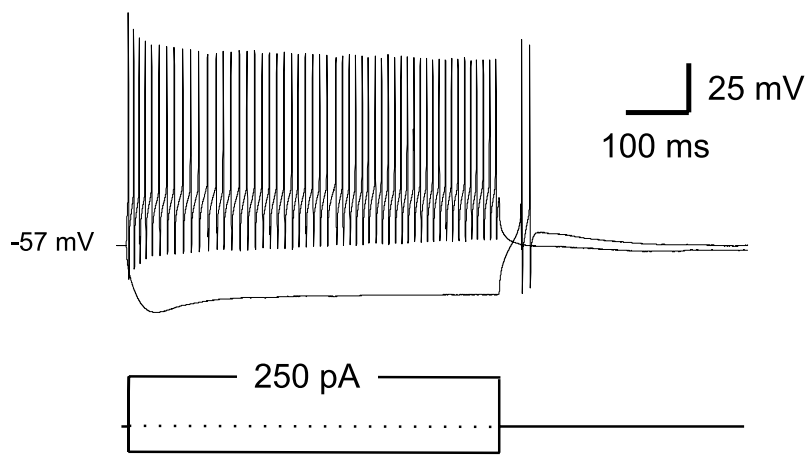

B

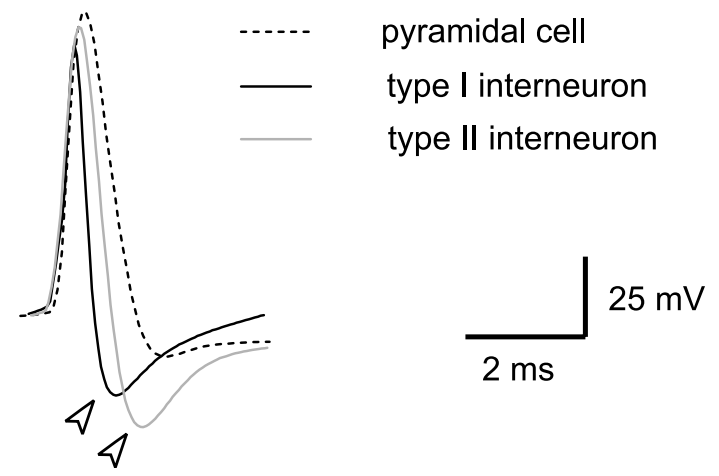

Figure 3. Active and passive electrophysiological properties of interneurons and pyramidal cells in layer III of the medial entorhinal cortex. A, A comparison of the action potential firing properties of interneurons and pyramidal cells in response to current injections at their respective resting membrane potentials. $\boldsymbol{B}$, Single action potential attributes of interneurons and a pyramidal cell. Arrowheads indicate the spike afterhyperpolarization.

and $95 \pm 10$ million in epileptic rats ( $58 \%$ of control; $p=0.008$ ). The average number of punctae per sample point also was reduced (control, $17.5 \pm 0.6$; epileptic, $10.6 \pm 0.5 ; p<0.0001$ ).

The total number of GABAergic neurons in all layers of the medial entorhinal cortex was estimated using stereological methods and in situ hybridization for GAD (Table 3, Fig. 7). Consis- 

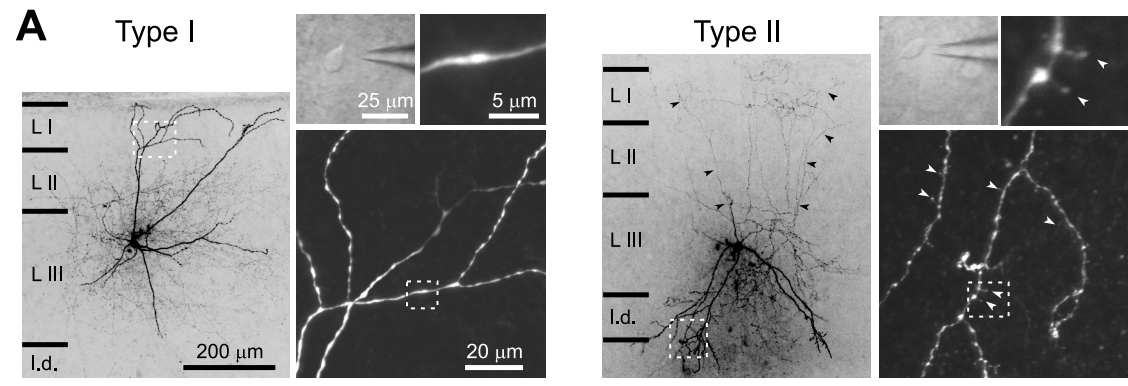

B
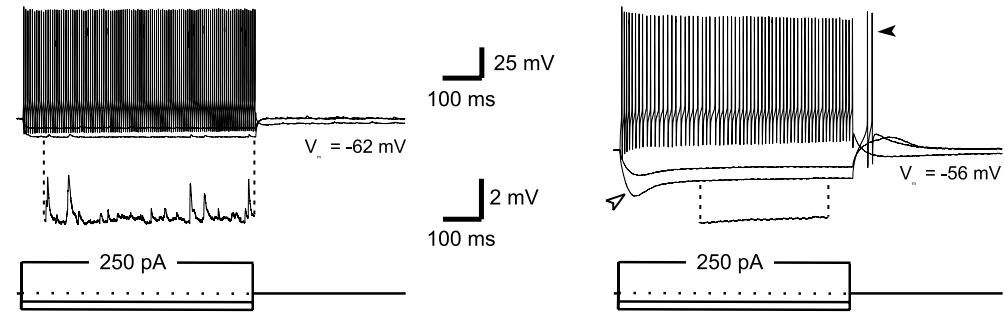

C
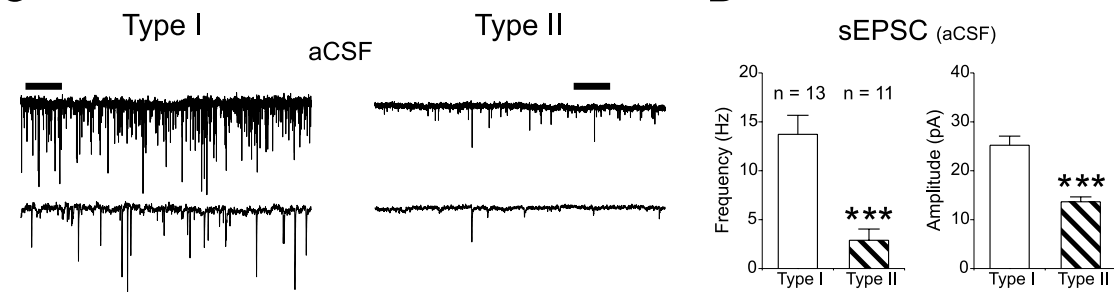

E

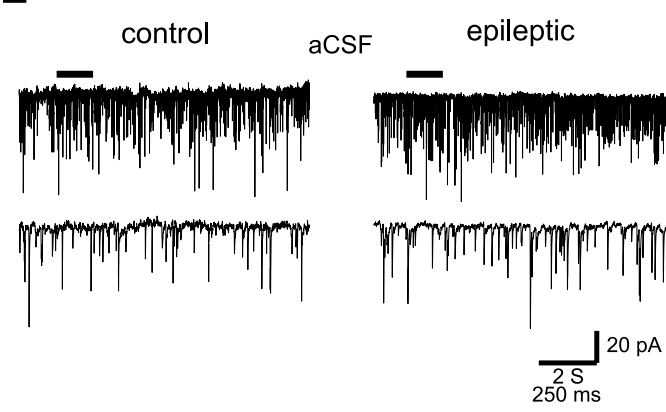

$\mathbf{F}$

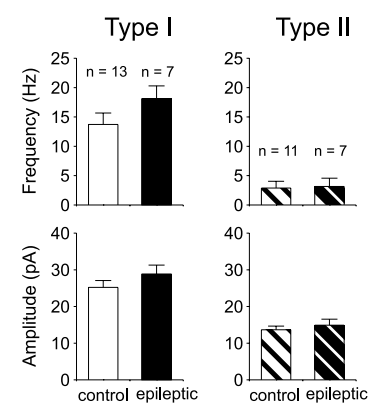

Figure 4. Anatomical and electrophysiological features of the two dominant types of inhibitory interneurons in layer III of the medial entorhinal cortex and their excitatory synaptic drive. $A$, Typical biocytin-labeled type I and type II interneurons showing differences in the orientation of their dendrites (thicker branches). The axon projections (thinner branches) of the two cell types are different: confined to the vicinity of the cell body and extending into layer II for type I and projecting to and ramifying in layer I for type II (black arrowheads). Magnified views of the boxed regions are shown on the right and in insets (top) of the respective figures, illustrating dendritic spines (white arrowheads) on type II interneurons but not type I interneurons. Differences in the shape of the cell bodies are subtle but distinguishable when examined with infrared differential-interference contrast optics (top inset). LI-LIII, Layers of the medial entorhinal cortex; I.d., lamina dissecans. B, Differences in the firing properties of the two cell types (at the indicated resting membrane potential) in response to current injections. Note the presence of spontaneous postsynaptic potentials in type interneurons that are seldom seen in type ll. Prominent sag currents (open arrowhead) and rebound burst firing (filled arrowhead) could be seen only in type II interneurons. C, D, A comparison of sEPSCs recorded at $-60 \mathrm{mV}$ in normal aCSF in both types of interneurons from control rats. Bar plots show a smaller average frequency and amplitude of sEPSCs in type Il interneurons compared with type I interneurons. Error bars indicate SEM. ${ }^{* * *} p<0.001, t$ test. $\boldsymbol{E}$, $\boldsymbol{F}$, There are no differences in mean frequency or amplitude of SEPSCs in epileptic rats compared with controls for either type of interneuron.

tent with the loss of GABAergic synapses, there were fewer GADpositive neurons per medial entorhinal cortex in epileptic rats compared with controls, and average GAD-positive neuron density was reduced to $82 \%$ of controls ( $8500 \pm 400$ vs $10,400 \pm 400$ cells $\left./ \mathrm{mm}^{3} ; p<0.004\right)$. The number of GAD-positive neurons was reduced to a similar extent in all layers: $81 \%$ of controls in layers I-II, $86 \%$ in layer III, and $82 \%$ in layers V-VI. The total number of Nissl-stained neurons in all layers of the medial entorhinal cortex was reduced in epileptic rats. The largest percentage reduction was in layer III ( $48 \%$ of controls), the smallest was in layers $\mathrm{V}-\mathrm{VI}$ $(75 \%)$, and layers I-II were intermediate $(67 \%)$.

\section{Discussion}

The principal findings of this study are that, in the medial entorhinal cortex of epileptic rats, (1) layer II stellate cells are hyperexcitable and receive a reduced frequency of sIPSCs and mIPSCs, (2) the frequency of sIPSCs in layer II stellate cells is equally sensitive to blockade of glutamate receptors in epileptic and control rats, (3) the frequency and amplitude of sEPSCs in layer III interneurons are normal, and (4) epileptic rats show a significant loss of GABAergic neurons in the entorhinal cortex and gephyrin-positive punctae in layers I-II. These findings suggest that hyperexcitability of layer II stellate cells is attributable, at least in part, to the loss of interneurons and inhibitory synapses and not to dormancy of interneurons as proposed previously.

\section{Interneurons in layer III of the entorhinal cortex}

Interneurons in layer III of the entorhinal cortex display electrophysiological and anatomical characteristics that distinguish them from pyramidal cells. Almost all of the interneurons examined fell into two clearly differentiated categories: type I or type II. Those few cells that did not fit either category were excluded from analysis. Based on previous studies in other cortical regions (Freund and Buzsáki, 1996; Cauli et al., 2000; Markram et al., 2004), type I interneurons are likely to be parvalbuminimmunoreactive basket cells, and type II interneurons resemble somatostatinpositive regular-spiking nonpyramidal cells. We did not confirm the immunocytochemical identity of the recorded interneurons, but parvalbumin- and somatostatin-positive interneurons are abundant in layer III of the medial entorhinal cortex (Miettinen et al., 1996; Wouterlood and Pothuizen, 2000). There may be additional, relatively rare types of interneurons, and we cannot exclude the possibility of their losing excitatory synaptic input.

In animal models of temporal lobe epilepsy, many GABAergic interneurons in the superficial layers of the entorhinal cortex persist after extensive loss of layer III pyramidal cells. However, previous studies of interneuron profile densities report mixed results, with slight interneuron loss in layer II (van Vliet et al., 2004) or layer III (Du et al., 1995), or no loss (Eid et al., 1999; 
A control epileptic

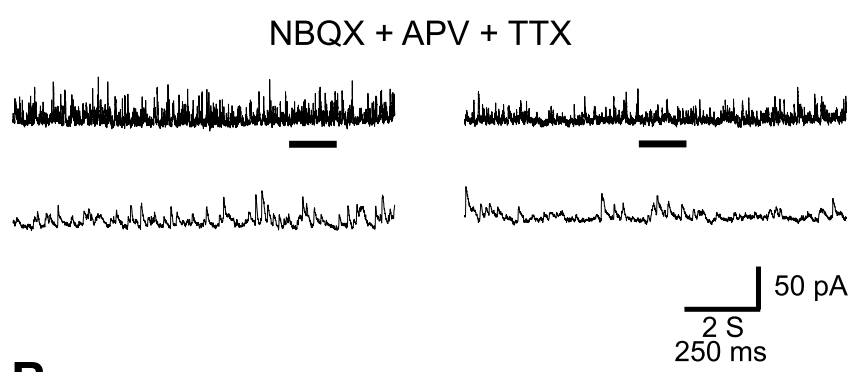

B

mIPSC (NBQX+AP5+TTX)
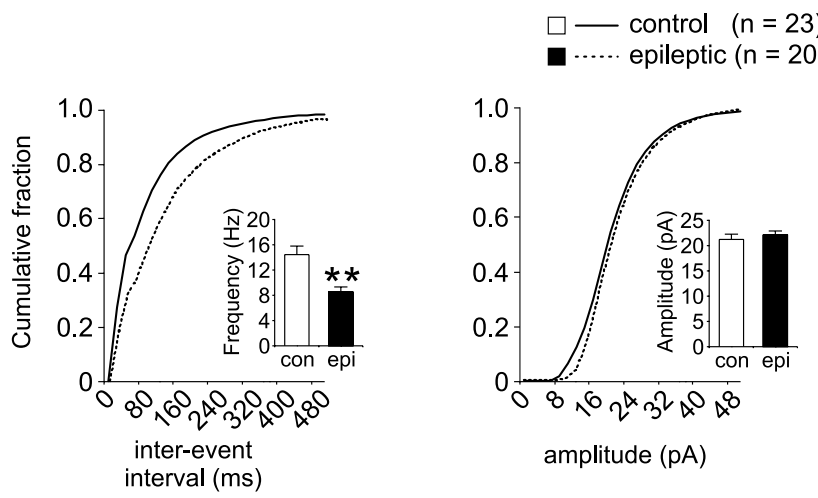

Figure 5. Electrophysiological evidence for loss of inhibitory synaptic input to layer ll stellate cells in the medial entorhinal cortex of epileptic rats. $\boldsymbol{A}$, Miniature IPSCs recorded in layer II stellate cells show reduced frequency in the epileptic group compared with controls. $\boldsymbol{B}$, Averaged cumulative distributions of interevent intervals (left; bin size, $20 \mathrm{~ms}$ ) and amplitudes (right; bin size, $2 \mathrm{pA}$ ) of mIPSCs recorded in layer II stellate cells from control and epileptic rats averaged over the indicated number of cells in each group. Bar plots (insets) represent the pooled data. Error bars indicate SEM. ${ }^{* *} p<0.01, t$ test.

Kobayashi et al., 2003; Tolner et al., 2005). Subtle differences between control and epileptic rats can be overlooked by qualitative assessments and density measures of neuron profiles in one or two sections. The present study used stereological methods to identify a significant loss of GAD-positive neurons in the medial entorhinal cortex of epileptic rats. Additional studies, however, are needed to identify which classes of interneurons are affected.

Consistent with the loss of GABAergic interneurons, there was a loss of gephyrin-positive punctae in layers I-II of the entorhinal cortex in epileptic rats. Gephyrin is a clustering/linker protein that colocalizes with $\alpha 1-3 / \gamma 2$ subunit-containing $\mathrm{GABA}_{\mathrm{A}}$ receptors (Essrich et al., 1998) and not with excitatory synapses (Giustetto et al., 1998). Gephyrin-positive punctae might occur at nonsynaptic sites, gephyrin may not be present at all synapses with $\mathrm{GABA}_{\mathrm{A}}$ receptors (Kneussel et al., 2001; Garin et al., 2002), and layers I-II of the entorhinal cortex include the apical tufts of deeper neurons. Despite these caveats, gephyrin is a convenient marker for estimating and comparing the number of GABAergic synapses, and its loss suggests that layer II stellate cells receive fewer inhibitory synapses in epileptic animals compared with controls.

The loss of gephyrin-positive punctae could be attributable to the loss of interneurons or their postsynaptic targets. In layers I-II, the predominant postsynaptic targets are likely to be stellate cells. Previous studies reported fewer layer II neurons in patients (Du et al., 1993) and models (van Vliet et al., 2004) of temporal lobe epilepsy. Consistent with these studies, we found that epileptic rats had significantly fewer Nissl-stained neurons in layers
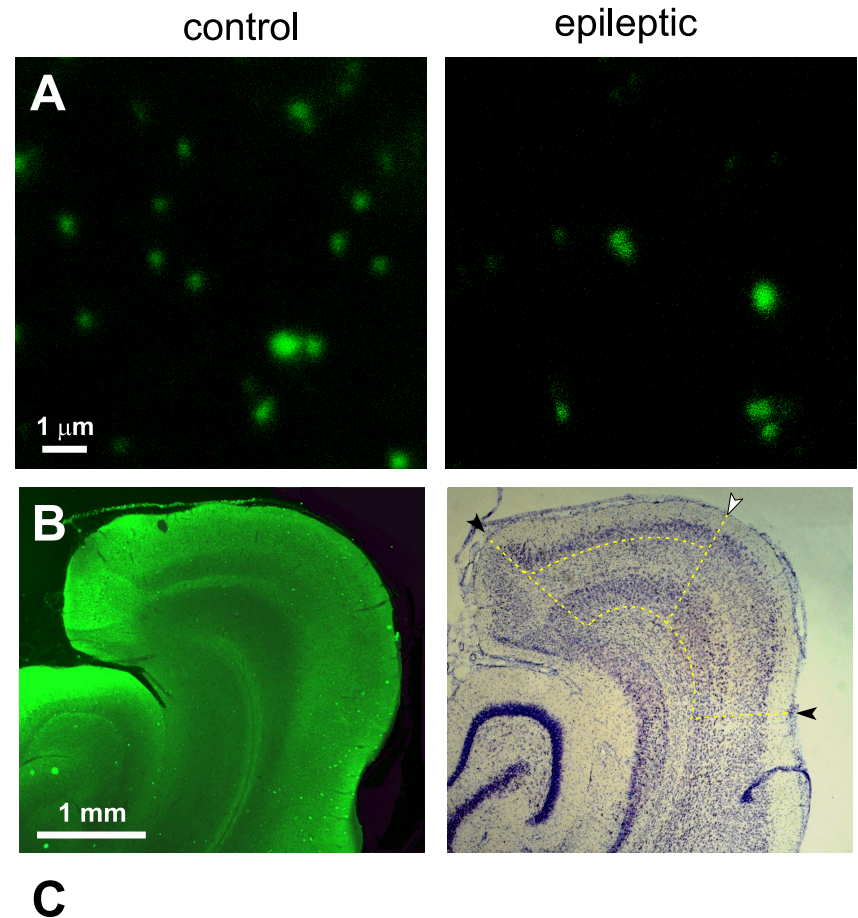

C

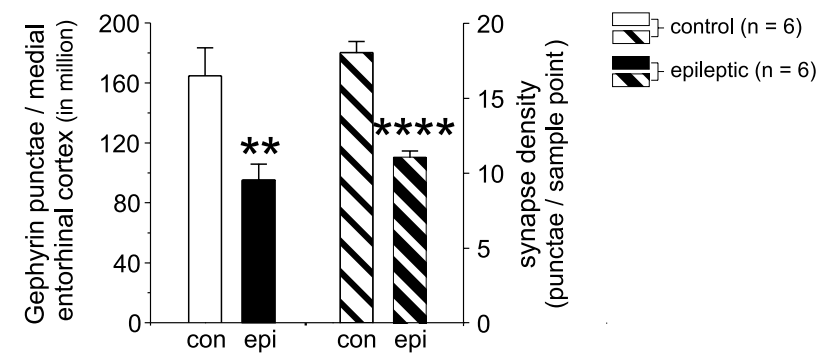

Figure 6. Anatomical evidence for loss of inhibitory synaptic input to layer II stellate cells in the entorhinal cortex of epileptic rats. $\boldsymbol{A}$, Images acquired by a laser scanning confocal microscopy of individual sample points in gephyrin-stained sections through the entorhinal cortex of control and epileptic rats. Each image is a composite of seven optical sections in the Z plane. $\boldsymbol{B}$, A low-powered image of the section used to acquire the control image in $\boldsymbol{A}$. Adjacent Nisslstained sections provided laminar information (right). Black arrowheads indicate the borders of the entorhinal cortex at the pail surface. A white arrowhead indicates the border of the medial and lateral entorhinal cortex. Dashed lines indicate the borders of the medial and lateral entorhinal cortex and layers I-II of the medial entorhinal cortex. $\boldsymbol{C}$, Pooled data of the number of gephyrin-positive punctae/entorhinal cortex (layers I-II only) averaged from the indicated number of animals in each group along with corresponding synapse density. con, Control rats; epi, epileptic rats. Error bars indicate SEM. ${ }^{* *} p<0.01,{ }^{* * *} p \ll 0.001, t$ test.

I-II than controls. However, the loss of gephyrin-positive punctae was greater than the loss of neurons in layers I-II, suggesting that reduction of GABAergic synapses was attributable to the loss of presynaptic interneurons and not just postsynaptic targets.

Given the significant loss of GAD-positive and Nissl-stained neurons in the entorhinal cortex, one might question whether the loss of inhibitory synaptic input to layer II stellate cells is counterbalanced by loss of excitatory synaptic input from other principal cells, including layer III pyramidal cells. Consistent with this hypothesis, the frequency of mEPSCs tended to be lower in layer II stellate cells in epileptic rats. However, individual interneurons typically make many more local synapses than principal cells, so their loss is likely to have a greater impact. Furthermore, in normal aCSF, the frequency of sIPSCs is significantly reduced $(57 \%$ of controls), whereas that of sEPSCs is increased (265\%) in layer II stellate cells of epileptic rats. These findings suggest that, under 
Table 3. Number of Nissl-stained and GAD65 mRNA-positive neurons per medial entorhinal cortex in control and epileptic rats

\begin{tabular}{llll}
\hline & $\begin{array}{l}\text { Control } \\
(n=10)\end{array}$ & $\begin{array}{l}\text { Epileptic } \\
(n=8)\end{array}$ & $\begin{array}{c}p \text { values } \\
(t \text { test })\end{array}$ \\
\hline NissI & & & \\
I-II & 107,900 & 72,500 & $<0.002$ \\
Mean & 7400 & 5200 & \\
SEM & 0.217 & 0.201 & \\
CV & 0.087 & 0.101 & $<0.000001$ \\
Mean CE ${ }^{a}$ & & & \\
III & 110,100 & 53,300 & $<0.009$ \\
Mean & 4400 & 4000 & \\
SEM & 0.125 & 0.211 & \\
CV & 0.058 & 0.089 & \\
Mean CE & & & \\
V-VI & 241,400 & 182,200 & \\
Mean & 10,900 & 17,400 & \\
SEM & 0.143 & 0.253 & \\
CV & 0.086 & 0.103 & \\
mean CE & & & \\
GAD & & & \\
I-VI & 38,500 & 28,700 & \\
Mean & 1400 & 1400 & \\
SEM & 0.118 & 0.134 & \\
CV & 0.050 & 0.062 & \\
Mean CE & & & \\
\hline
\end{tabular}

CV, Coefficient of variation; CE, coefficient of error.

${ }^{a}$ Mean CE was calculated as described by West et al. (1991).
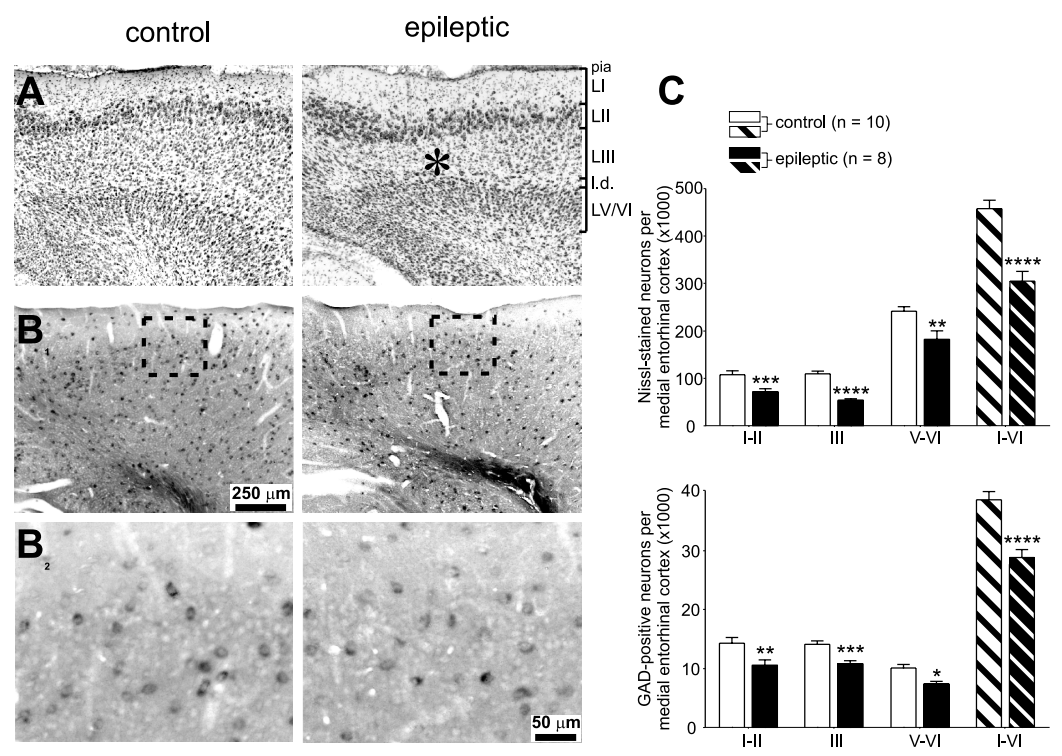

Figure 7. Stereological evidence for loss of GABAergic interneurons in the entorhinal cortex of epileptic rats. A, Images of control (left) and epileptic (right) Nissl-stained sections reveal preferential loss $\left(^{*}\right)$ of layer III pyramidal cells. Layers are indicated (LI-LVI; I.d., lamina dissecans). $\boldsymbol{B}_{1}$, Adjacent sections from the same animals processed for GAD65 mRNA in situ hybridization. $\boldsymbol{B}_{2^{\prime}}$ Higher-magnification images of the regions indicated by boxes in $\boldsymbol{B}_{1}$. $\boldsymbol{C}$, Epileptic animals had fewer Niss-stained neurons and GAD-positive cells in all layers of the entorhinal cortex. ${ }^{*} p<0.05,{ }^{* *} p<0.01,{ }^{* * *} p<0.005,{ }^{* * * *} p<0.001, t$ test.

baseline conditions, layer II stellate cells in epileptic rats receive excessive excitatory synaptic input and insufficient inhibitory input.

\section{Mechanisms of layer II stellate cell hyperexcitability}

Previous electrophysiological evidence that supports the dormant interneuron hypothesis includes similar monosynaptic IPSPs in layer II stellate cells of control and epileptic rats (Bear et al., 1996) and reduced frequency of sIPSCs but not mIPSCs in pilocarpine-treated rats, 3-7 d after status epilepticus (Kobayashi et al., 2003). To evaluate the dormant interneuron hypothesis more completely, we tested its predictions that glutamate receptor blockers should have less effect on the frequency of sIPSCs in layer II stellate cells in epileptic rats, that layer III interneurons should have a reduced frequency of sEPSCs, and that the frequency of mIPSCs in layer II stellate cells should be normal. None of these predictions was upheld.

Considering the loss of more than half of the layer III pyramidal cells in epileptic animals, it is surprising that the excitatory synaptic drive to surviving, nearby interneurons appeared to be intact. The frequency of sEPSCs in interneurons from epileptic rats was $132 \%$ of controls, suggesting strong synaptic input. A partial loss of excitatory synapses, however, might have been masked by increased spontaneous activity of their presynaptic excitatory neurons. Despite this caveat, the high frequency of sEPSCs indicates that interneurons were excited by afferents arising from neurons other than the vulnerable population of layer III pyramidal cells. The source of the persistent excitatory synapses to layer III interneurons is unknown. Possibilities include layer II stellate cells, surviving layer III pyramidal cells, pyramidal cells in layers V and VI, and neurons in regions outside of the entorhinal cortex, including the presubiculum (van Haeften et al., 2003; Honda and Ishizuka, 2004; Tolner et al., 2005).

The present study focused on layer III interneurons in the medial entorhinal cortex because of their pivotal position in the dormant interneuron hypothesis. Interneurons in layers I and II, however, are likely to provide much of the inhibitory synaptic input to layer II stellate cells. We did not evaluate sEPSCs of layer I and II interneurons, but, if they were dormant, one would expect that blocking glutamatergic synaptic transmission would have had less of an effect on the frequency of sIPSCs in layer II stellate cells of epileptic rats compared with controls. That was not the case.

In epileptic rats, the number of gephyrinpositive punctae and the frequency of mIPSCs and sIPSCs of layer II stellate cells were reduced to similar levels (57-59\% of controls), suggesting that a single mechanism, loss of inhibitory synapses, might account for the electrophysiological and anatomical data. The loss of GABAergic synaptic input to layer II stellate cells is likely to contribute to their hyperexcitability and may be epileptogenic. However, other potential epileptogenic mechanisms could contribute, including changes in channel properties (Agrawal et al., 2003; Bernard et al., 2004; Shah et al., 2004), changes in receptor expression and function (Buhl et al., 1996; Brooks-Kayal 
et al., 1998; Huang et al., 2002), including $\mathrm{GABA}_{\mathrm{B}}$ receptors (Straessle et al., 2003), and axon sprouting (Tauck and Nadler, 1985; Perez et al., 1996; Esclapez et al., 1999).

The dormant interneuron hypothesis has been proposed as a mechanism of temporal lobe epileptogenesis in the dentate gyrus (Sloviter, 1987; Sloviter et al., 2003), CA1 region (Sloviter, 1991; Bekenstein and Lothman, 1993), and entorhinal cortex (Du et al., 1995; Bear et al., 1996; Eid et al., 1999) but has met with difficulty (Bernard et al., 1998). In the dentate gyrus, input from CA3 pyramidal cells to interneurons is weakened (Doherty and Dingledine, 2001), but reduced inhibition of granule cells is more closely related to the loss of interneurons than to interneuron dormancy (Williamson et al., 1999; Kobayashi and Buckmaster, 2003; Sayin et al., 2003; Shao and Dudek, 2005). The CA1 region displays evidence of reduced excitatory synaptic drive to interneurons and loss of interneurons (Mangan et al., 1995; Morin et al., 1998; Dinocourt et al., 2003), but surviving interneurons are not dormant (Rempe et al., 1997; Cossart et al., 2001). The present study used electrophysiological and anatomical methods to demonstrate for the first time that loss, not dormancy, of inhibitory neurons is a more likely mechanism of reduced inhibition of layer II stellate cells in the entorhinal cortex. Collectively, these findings suggest that the same mechanism, loss of interneurons and GABAergic synapses, reduces inhibition in closely interconnected structures of the limbic system, which could have a synergistic, hyperexcitable effect and be an important pathophysiological feature of temporal lobe epilepsy.

\section{References}

Agrawal N, Alonso A, Ragsdale DS (2003) Increased persistent sodium currents in rat entorhinal cortex layer $\mathrm{V}$ neurons in a post-status epilepticus model of temporal lobe epilepsy. Epilepsia 44:1601-1604.

Alonso A, Klink R (1993) Differential electroresponsiveness of stellate and pyramidal-like cells of medial entorhinal cortex layer II. J Neurophysiol 70:128-143.

Bartolomei F, Khalil M, Wendling F, Sontheimer A, Régis J, Ranjeva J-P, Guye M, Chauvel P (2005) Entorhinal cortex involvement in human mesial temporal lobe epilepsy: an electrophysiological and volumetric study. Epilepsia 45:677-687.

Bear J, Fountain NB, Lothman EW (1996) Responses of the superficial entorhinal cortex in vitro in slices from naive and chronically epileptic rats. J Neurophysiol 76:2928-2940.

Bekenstein JW, Lothman EW (1993) Dormancy of inhibitory interneurons in a model of temporal lobe epilepsy. Science 259:97-100.

Bernard C, Esclapez M, Hirsch JC, Ben-Ari Y (1998) Interneurons are not so dormant in temporal lobe epilepsy: a critical reappraisal of the dormant basket cell hypothesis. Epilepsy Res 32:93-103.

Bernard C, Anderson A, Becker A, Poolos NP, Beck H, Johnston D (2004) Acquired dendritic channelopathy in temporal lobe epilepsy. Science 305:532-535.

Bernasconi N, Bernasconi A, Andermann F, Dubeau F, Feindel W, Reutens DC (1999) Entorhinal cortex in temporal lobe epilepsy: a quantitative MRI study. Neurology 52:1870-1876.

Bragin A, Jandó G, Nádasdy Z, van Landeghem M, Buzsáki G (1995) Dentate EEG spikes and associated interneuronal population bursts in the hippocampal hilar region of the rat. J Neurophysiol 73:1691-1705.

Brooks-Kayal AR, Shumate MD, Jin H, Rikhter TY, Coulter DA (1998) Selective changes in single cell GABA(A) receptor subunit expression and function in temporal lobe epilepsy. Nat Med 4:1166-1172.

Buckmaster PS (2004) Laboratory animal models of temporal lobe epilepsy. Comp Med 54:473-485.

Buckmaster PS, Dudek FE (1997) Network properties of the dentate gyrus in epileptic rats with hilar neuron loss and granule cell axon reorganization. J Neurophysiol 77:2685-2696.

Buckmaster PS, Jongen-Rêlo AL (1999) Highly specific neuron loss preserves lateral inhibitory circuits in the dentate gyrus of kainate-induced epileptic rats. J Neurosci 19:9519-9529.

Buckmaster PS, Alonso A, Canfield DR, Amaral DG (2004) Dendritic mor- phology, local circuitry, and intrinsic electrophysiology of principal neurons in the entorhinal cortex of macaque monkeys. J Comp Neurol 470:317-329.

Buhl EH, Otis TS, Mody I (1996) Zinc-induced collapse of augmented inhibition by GABA in a temporal lobe epilepsy model. Science 271:369-373.

Cauli B, Porter JT, Tsuzuki K, Lambolez B, Rossier J, Quenet B, Audinat E (2000) Classification of fusiform neocortical interneurons based on unsupervised clustering. Proc Natl Acad Sci USA 97:6144-6149.

Clifford DB, Olney JW, Maniotis A, Collins RC, Zorumski CF (1987) The functional anatomy and pathology of lithium-pilocarpine and high-dose pilocarpine seizures. Neuroscience 23:953-968.

Cossart R, Dinocourt C, Hirsch JC, Merchan-Perez A, De Felipe J, Ben-Ari Y, Esclapez M, Bernard C (2001) Dendritic but not somatic GABAergic inhibition is decreased in experimental epilepsy. Nat Neurosci 4:52-62.

Dawodu S, Thom M (2005) Quantitative neuropathology of the entorhinal cortex region in patients with hippocampal sclerosis and temporal lobe epilepsy. Epilepsia 46:23-30.

de Curtis M, Paré D (2004) The rhinal cortices: a wall of inhibition between the neocortex and the hippocampus. Prog Neurobiol 74:101-110.

Dinocourt C, Petanjek Z, Freund TF, Ben-Ari Y, Esclapez M (2003) Loss of interneurons innervating pyramidal cell dendrites and axon initial segments in the CA1 region of the hippocampus following pilocarpineinduced seizures. J Comp Neurol 459:407-425.

Doherty J, Dingledine R (2001) Reduced excitatory drive onto interneurons in the dentate gyrus after status epilepticus. J Neurosci 21:2048-2057.

Du F, Whetsell Jr WO, Abou-Khalil B, Blumenkopf B, Lothman EW, Schwarcz R (1993) Preferential neuronal loss in layer III of the entorhinal cortex in patients with temporal lobe epilepsy. Epilepsy Res 16:223-233.

Du F, Eid T, Lothman EW, Köhler C, Schwarcz R (1995) Preferential neuronal loss in layer III of the medial entorhinal cortex in rat models of temporal lobe epilepsy. J Neurosci 15:6301-6313.

Eid T, Schwarcz R, Ottersen OP (1999) Ultrastructure and immunocytochemical distribution of GABA in layer III of the rat medial entorhinal cortex following aminooxyacetic acid-induced seizures. Exp Brain Res 125:463-475.

Engel Jr J, Williamson PD, Wieser HG (1997) Mesial temporal lobe epilepsy. In: Epilepsy: a comprehensive textbook (Engel Jr J, Pedley TA, eds), pp 2417-2426. Philadelphia: Lippincott-Raven.

Erlander MG, Tillakaratne NJ, Feldblum S, Patel N, Tobin AJ (1991) Two genes encode distinct glutamate decarboxylases. Neuron 7:91-100.

Esclapez M, Hirsch JC, Ben-Ari Y, Bernard C (1999) Newly formed excitatory pathways provide a substrate for hyperexcitability in experimental temporal lobe epilepsy. J Comp Neurol 408:449-460.

Essrich C, Lorez M, Benson JA, Fritschy JM, Luscher B (1998) Postsynaptic clustering of major $\mathrm{GABA}_{\mathrm{A}}$ receptor subtypes requires the gamma 2 subunit and gephyrin. Nat Neurosci 1:563-571.

Freund TF, Buzsáki G (1996) Interneurons of the hippocampus. Hippocampus 6:347-470.

Garin N, Hornung J-P, Escher G (2002) Distribution of postsynaptic $\mathrm{GABA}_{\mathrm{A}}$ receptor aggregates in the deep cerebellar nuclei of normal and mutant mice. J Comp Neurol 447:210-217.

Giustetto M, Kirsch J, Fritschy JM, Cantino D, Sassoe-Pognetto M (1998) Localization of the clustering protein gephyrin at GABAergic synapses in the main olfactory bulb of the rat. J Comp Neurol 395:231-244.

Honda Y, Ishizuka N (2004) Organization of connectivity of the rat presubiculum. I. Efferent projections to the medial entorhinal cortex. J Comp Neurol 473:463-484.

Huang Y, Doherty JJ, Dingledine R (2002) Altered histone acetylation at glutamate receptor 2 and brain-derived neurotrophic factor genes is an early event triggered by status epilepticus. J Neurosci 22:8422-8428.

Jones RS (1994) Synaptic and intrinsic properties of neurons of origin of the perforant path in layer II of the rat entorhinal cortex in vitro. Hippocampus 4:335-353.

Jutila L, Ylinen A, Partanen K, Alafuzoff I, Mervaala E, Partanen J, Vapalahti M, Vainio P, Pitkanen A (2001) MR volumetry of the entorhinal, perirhinal, and temporopolar cortices in drug-refractory temporal lobe epilepsy. Am J Neuroradiol 22:1490-1501.

Kneussel M, Brandstätter JH, Gasnier B, Feng G, Sanes JR, Betz H (2001) Gephyrin-independent clustering of postsynaptic $\mathrm{GABA}_{\mathrm{A}}$ receptor subtypes. Mol Cell Neurosci 17:973-982. 
Kobayashi M, Buckmaster PS (2003) Reduced inhibition of dentate granule cells in a model of temporal lobe epilepsy. J Neurosci 23:2440-2452.

Kobayashi M, Wen X, Buckmaster PS (2003) Reduced inhibition and increased output of layer II neurons in the medial entorhinal cortex in a model of temporal lobe epilepsy. J Neurosci 23:8471-8479.

Mangan PS, Rempe DA, Lothman EW (1995) Changes in inhibitory neurotransmission in the CA1 region and dentate gyrus in a chronic model of temporal lobe epilepsy. J Neurophysiol 74:829-840.

Markram H, Toledo-Rodriguez M, Wang Y, Gupta A, Silberberg G, Wu C (2004) Interneurons of the neocortical inhibitory system. Nat Rev Neurosci 5:793-807.

Miettinen M, Koivisto E, Riekkinen Sr P, Miettinen R (1996) Coexistence of parvalbumin and GABA in nonpyramidal neurons of the rat entorhinal cortex. Brain Res 706:113-122.

Morin F, Beaulieu C, Lacaille J-C (1998) Cell-specific alterations in synaptic properties of hippocampal CA1 interneurons after kainate treatment. J Neurophysiol 80:2836-2847.

Mulders WHAM, West MJ, Slomianka L (1997) Neuron numbers in the presubiculum, parasubiculum, and entorhinal area of the rat. J Comp Neurol 385:83-94.

Paxinos G, Watson C (1998) The rat brain in stereotaxic coordinates, Ed 4. New York: Academic.

Perez Y, Morin F, Beaulieu C, Lacaille J-C (1996) Axonal sprouting of CAl pyramidal cells in hyperexcitable hippocampal slices of kainate-treated rats. Eur J Neurosci 8:736-748.

Ramón y Cajal S (1995) Histology of the nervous system of man and vertebrates, Vol 2 (Swanson N, Swanson LW, translators), pp 626-637. New York: Oxford UP.

Rempe DA, Bertram EH, Williamson JM, Lothman EW (1997) Interneurons in area CA1 stratum radiatum and stratum oriens remain functionally connected to excitatory synaptic input in chronically epileptic animals. J Neurophysiol 78:1504-1515.

Ribak CE, Seress L, Weber P, Epstein CM, Henry TR, Bakay RA (1998) Alumina gel injections into the temporal lobe of rhesus monkeys cause complex partial seizures and morphological changes found in human temporal lobe epilepsy. J Comp Neurol 401:226-290.

Rutecki PA, Grossman RG, Armstrong D, Irish-Loewen S (1989) Electrophysiological connections between the hippocampus and entorhinal cortex in patients with complex partial seizures. J Neurosurg 70:667-675.

Sayin U, Osting S, Hagen J, Rutecki P, Sutula T (2003) Spontaneous seizures and loss of axo-axonic and axo-somatic inhibition induced by repeated brief seizures in kindled rats. J Neurosci 23:2759-2768.

Scharfman HE, Goodman JH, Du F, Schwarcz R (1998) Chronic changes in synaptic responses of entorhinal and hippocampal neurons after aminooxyacetic acid (AOAA)-induced entorhinal cortical neuron loss. J Neurophysiol 80:3031-3046.

Schwarcz R, Tore E, Du F (2000) Neurons in layer III of the entorhinal cortex: a role in epileptogenesis and epilepsy? Ann NY Acad Sci 911:328-342.

Schwob JE, Fuller T, Price JL, Olney JW (1980) Widespread patterns of neuronal damage following systemic or intracerebral injections of kainic acid: a histological study. Neuroscience 5:991-1014.

Segal M, Landis S (1974) Afferents to the hippocampus of the rat studied with the method of retrograde transport of horseradish peroxidase. Brain Res 78:1-15.

Shah MM, Anderson AE, Leung V, Lin X, Johnston D (2004) Seizureinduced plasticity of $\mathrm{h}$ channels in entorhinal cortical layer III pyramidal neurons. Neuron 44:495-508.
Shao L-R, Dudek FE (2005) Changes in mIPSCs and sIPSCs after kainate treatment: evidence for loss of inhibitory input to dentate granule cells and possible compensatory responses. J Neurophysiol 94:952-960.

Sloviter RS (1987) Decreased hippocampal inhibition and a selective loss of interneurons in experimental epilepsy. Science 235:73-76.

Sloviter RS (1991) Permanently altered hippocampal structure, excitability, and inhibition after experimental status epilepticus in the rat: the "dormant basket cell" hypothesis and its possible relevance to temporal lobe epilepsy. Hippocampus 1:41-66.

Sloviter RS, Zappone CA, Harvey BD, Bumanglag AV, Bender RA, Frotscher M (2003) "Dormant basket cell" hypothesis revisited: relative vulnerabilities of dentate gyrus mossy cells and inhibitory interneurons after hippocampal status epilepticus in the rat. J Comp Neurol 459:44-76.

Steward O, Scoville SA (1976) Cells of origin of entorhinal cortical afferents to the hippocampus and fascia dentata of the rat. J Comp Neurol 169:347-370.

Straessle A, Loup F, Arabadzisz D, Ohning GV, Fritschy J-M (2003) Rapid and long-term alterations of hippocampal $\mathrm{GABA}_{\mathrm{B}}$ receptors in a mouse model of temporal lobe epilepsy. Eur J Neurosci 18:2213-2226.

Tauck DL, Nadler JV (1985) Evidence of functional mossy fiber sprouting in hippocampal formation of kainic acid-treated rats. J Neurosci 5:1016-1022.

Tolner EA, Kloosterman F, van Vliet EA, Witter MP, Lopes da Silva FH, Gorter JA (2005) Presubiculum stimulation in vivo evokes distinct oscillations in superficial and deep entorhinal cortex layers in chronic epileptic rats. J Neurosci 25:8755-8765.

Turski L, Ikonomidou C, Turski WA, Bortolotto ZA, Cavalheiro EA (1989) Review: cholinergic mechanisms and epileptogenesis. The seizures induced by pilocarpine: a novel experimental model of intractable epilepsy. Synapse 3:154-171.

van Haeften T, Baks-te-Bulte L, Goede PH, Wouterlood FG, Witter MP (2003) Morphological and numerical analysis of synaptic interactions between neurons in deep and superficial layers of the entorhinal cortex of the rat. Hippocampus 13:943-952.

van Vliet EA, Aronica E, Tolner EA, Lopes da Silva FH, Gorter JA (2004) Progression of temporal lobe epilepsy in the rat is associated with immunocytochemical changes in inhibitory interneurons in specific regions of the hippocampal formation. Exp Neurol 187:367-379.

West MJ, Slomianka L, Gundersen HJ (1991) Unbiased stereological estimation of the total number of neurons in the subdivisions of the rat hippocampus using the optical fractionator. Anat Rec 231:482-497.

Williamson A, Patrylo PR, Spencer DD (1999) Decrease in inhibition in dentate granule cells from patients with medial temporal lobe epilepsy. Ann Neurol 45:92-99.

Wilson CL, Isokawa M, Babb TL, Crandall PH (1990) Functional connections in the human temporal lobe. Exp Brain Res 82:279-292.

Witter MP, Groenewegen HJ, Lopes da Silva FH, Lohman AHM (1989) Functional organization of the extrinsic and intrinsic circuitry of the parahippocampal region. Prog Neurobiol 33:161-253.

Woodhall GL, Bailey SJ, Thompson SE, Evans DIP, Jones RSG (2005) Fundamental differences in spontaneous synaptic inhibition between deep and superficial layers of the rat entorhinal cortex. Hippocampus 15:232-245.

Wouterlood FG, Pothuizen H (2000) Sparse colocalization of somatostatinand GABA-immunoreactivity in the entorhinal cortex of the rat. Hippocampus 10:77-86. 